\title{
INCOME EFFICIENCY OF CASSAVA FARMING IN CISEENG SUB-DISTRICT BOGOR REGENCY
}

\author{
Lola Rahmadona); Rizka Endah Agustin'); \\ ${ }^{1,2)}$ Agriculture Faculty, Muhammadiyah University of Jakarta \\ Email: ${ }^{1)}$ lola.rahmadona@umj.ac.id; ${ }^{2)}$ rizkaea26@gmail.com
}

\section{How to Cite :}

Rahmadona, L., Agustin, R. E. 2021. Income Efficiency of Cassava Farming in Ciseeng Sub-District Bogor Regency. Journal of Agri Socio Economics and Business. 3 (2): 81-90. DOI: https://doi.org/10.31186/jaseb.03.2.81-90

\section{ARTICLE HISTORY \\ Received [19 Nov 2021] \\ Revised [21 Dec 2021] \\ Accepted [22 Dec 2021]}

\section{KEYWORDS}

Cassava,

Efficiency, ration
Characteristics,

Income, $R / C$
This is an open access article under the $C C-B Y-S A$ license

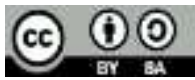

\section{ABSTRACT}

Cassava is the third food crop in Indonesia after rice and maize. Ciseeng Subdistrict was selected as the study site because it is one of the centers of cassava production in Bogor Regency. The method used is mixed methods and its implementation using survey techniques. Respondents were determined intentionally (purposive) with a total of 30 farmers. The declining interest of farmers is a problem in the cassava farming activities in Ciseeng Subdistrict. This study aimed to determine the characteristics and efficiency of cassava farming income in Ciseeng Subdistrict. In this study, the characteristics described in the descriptive and efficiency of farming income using analysis of $R / C$ ratio. The analysis results showed that the income from cash costs and total costs on cassava farming in Ciseeng Subdistrict has a value greater than zero. Revenue from cash costs is IDR 17.162.017,14 per hectare, and total costs are IDR 7.901.952,86 per hectare. The results of the $R / C$ ratio analysis also showed that cassava farming in Ciseeng Subdistrict was worth more than one. The $R / C$ ratio of cash costs is 2,45, and the total costs are 1,38. So it can be said that cassava farming in Ciseeng Subdistrict is efficient or feasible to be developed.

\section{INTRODUCTION}

Food crops are an agricultural sub-sector that is very strategic in realizing national food security. Food crops also play a role in achieving regional development, poverty alleviation, employment, providing industrial raw materials, saving, and receiving state foreign exchange. In addition, food crops are attractors for upstream industries and growth drivers for downstream sectors (Ministry of Agriculture, 2016). 
Cassava is one of the food substitutes for rice which has an important role in supporting the food security of a region. Cassava is the third food crop commodity in Indonesia after rice and corn. In addition to being a food source of carbohydrates, cassava can also be used as animal feed and industrial raw materials (Ministry of Agriculture, 2016).

Indonesia has several cassava production centers, one of which is Java. The provinces of cassava production centers on the island of Java are East Java, Central Java, West Java, and Special Region Yogyakarta. West Java Province ranks third as a cassava production center province on the island of Java. West Java is one of the provinces designated as cassava development areas by Kepmentan No.03/Kpts/PD.120/1/2015 concerning the Designation of Regencies/Cities as Rice, Corn, Soybean, and Cassava Areas. Specifically for cassava, regional development in West Java is set in 7 districts, namely Bogor, Sukabumi, Cianjur, Bandung, Tasikmalaya, Sumedang, and Subang.

Bogor Regency is one of the cassava production and cassava development areas in West Java Province. One of the sub-districts that has become a cassava development area is Ciseeng sub-district. Ciseeng sub-district has a large area of cassava land for farming. It can develop cassava farming activities with a land area of 150 hectares, production of 3,448 tons, and productivity of 23.004 tons per hectare (Horticulture and Plantation Office of Bogor Regency, 2019). However, the high land area owned is not proportional to the production results obtained, resulting in a decrease in cassava productivity. This is also due to the decreasing interest of farmers in cassava farming because there is no certainty of selling prices at the farmer level-fluctuations in the selling price of cassava impact the income earned by farmers. In addition to fluctuating selling prices, many factors affect the income of cassava farming, among others, caused by the inadequate level of technological mastery. The use of farming production factors is not optimal.

Income is the main priority in running a farm. Farming is good if the output produced is greater than the input used (Rahmadona et al., 2016). In addition, efficiency also needs to be considered in running the farm to determine the effectiveness. The efficiency level of farming depends on how farmers can improve the effectiveness of production factors provided so that the production is optimal.

This study aims to analyze the characteristics of farmers, the use of production facilities, and the efficiency of cassava farming income in Ciseeng sub-district. The analysis results are then expected to help cassava farmers in Ciseeng sub-district in the process of developing their farms.

\section{RESEARCH METHODS}

\section{Method of Collecting Data}

This research was conducted in Ciseeng sub-district. The research location was chosen purposively considering that Ciseeng sub-district is one of the cassava production centers in Bogor Regency.

Determination of the sample using purposive method where the researcher determines the sampling by setting criteria by the research objectives. The requirements for the sample in this study were farmers with land ownership ranging from 0.5 hectares to 2 hectares and a minimum farming period of three years. 
According to Arikunto (2010), the sampling theory is if the research population is more than 100, then the sample can be taken between 10-15 percent or 20-25 percent. The sampling in this study is 25 percent of the existing population because the population exceeds 100 , i.e., 119 farmers. The sampling calculation is as follows: $25 \%$ $\times 119=30$. So, the sample used in this study was 30 farmers.

\section{Data Analysis Method}

The data analysis method used is the quantitative analysis method. The quantitative analysis aims to analyze the efficiency of cassava farming income in Ciseeng sub-district.

Quantitative analysis was carried out using cost analysis, farm income, and cost balance analysis ( $R / C$ analysis). The primary data collected first went through a data verification and validation process before processing.

The results of primary data processing are presented in the form of tables which are then interpreted in the form of discussions. According to Soekartawi (2016), to determine the efficiency of farm income, mathematical calculations are needed with the following formula:

\section{Cost Analysis}

Total costs are the sum of fixed and variable costs used together in the production process. Systematically can be formulated as follows:

$\mathrm{TC}=\mathrm{FC}+\mathrm{VC}$

Description:

TC: Total Cost

FC: Fixed Costs

VC: Variable Cost

\section{Revenue Analysis}

Revenue is obtained by multiplying the amount of production by the selling price of the product. It can be systematically formulated as follows:

$\mathrm{TR}=\mathrm{Y} \times \mathrm{Py}$

Description:

TR : Total Revenue (IDR)

$\mathrm{Y}$ : Production obtained $(\mathrm{Kg})$

Py : Price Y (IDR)

\section{Income Analysis}

Farming can be good or profitable if the output produced is larger than the input used. Systematically can be formulated as follows:

$\mathrm{Y}=\mathrm{TR}-\mathrm{TC}$

Description:

Y: Farm Income

TR: Total Revenue

TC: Total Expenses 


\section{Efficiency Analysis}

The farm is efficient if the ratio between revenues and expenditures has results $>1$. The efficiency of a farm can be known by calculating the R/C ratio, which can be systematically formulated as follows:

$\mathrm{R} / \mathrm{C}=\mathrm{TR} / \mathrm{TC}$

Description:

$\mathrm{R} / \mathrm{C}$ : Comparison between costs and revenues

TR: Total Revenue

TC : Total Expenditure

\section{RESULTS AND DISCUSSION}

\section{Farmers Characteristics}

The number of farmers in this study was 30 cassava farmers taken by the purposive sampling method. Several aspects can describe the research object, including the farmer's age, formal education, land area, farming experience, and the number of family dependents. Here is the explanation:

1. Age

Age is the length of time they lived from birth or existed until this research was conducted. In the demographic analysis, the age structure of the population is divided into three groups, namely (a) the young age group, under 15 years; (b) productive age group, 15 - 64 years old; and (c) old age group; age 65 years and over (Tjiptoherijanto, 2001).

The distribution of farmers based on age shows that the largest number of farmers is on an age scale of $45-54$ years with a percentage of 30 percent. These data indicate that farmers of productive age carry out cassava farming activities in Ciseeng sub-district. The productive age is the ideal age to work well and is still strong to carry out activities inside and outside the farm.

A study conducted by Nandi et al. (2011) found that farmers aged 30 - 59 years were more productive than farmers aged 60 years and over because they were still active and very energetic. Udoh et al. (2006) found that farmer age positively affects their technical efficiency.

2. Formal Education

Research data shows that seventeen farmers graduated from elementary school with 56.67 percent. Eight farmers graduated from junior high school with a percentage of 26.67 percent. Farmers who graduated from high school were five people with a rate of 16.67 percent, and none of the farmers completed their education at the tertiary level. These results indicate that the level of formal education in Ciseeng sub-district is still relatively low.

The largest percentage of expenditure is on the cost of seeds of 85.28 percent. The second-largest percentage of expenditure is TKDK costs of 13.55 percent. The smallest percentage of expenses calculated is on equipment depreciation costs of 1.17 percent. The total cost of cassava farming in Ciseeng sub-district is IDR 9,260,064.28 per hectare. A low level of education may be implicated in the lack of coordination planning for farms, so the use of factors of production is less than optimal.

According to Amanze et al. (2010), a farmer's level of education increases productivity and increases the ability to understand and evaluate new production

84| Rosilawati, N., K. Sukiyono, Sriyoto. Income Efficiency of Cassava Farming.... 
techniques. Bamidele et al. (2008) also noted that when farmers are educated, they will appreciate technology improvements and even use it appropriately to increase their farm's output. Education will increase the efficiency of farmers because it allows them to access better technology, thereby increasing the output of their farm (Adeyemo et al., 2010).

\section{Land Area}

Sayogyo (1977) classifies farmers in Java into three categories: small-scale farmers with a farm area of $<0.5$ hectares, medium-scale farmers with a farm area of 0.5 - 1.0 hectares, and small-scale area with a farm area of $>1.0$ hectares. The total arable area of the 30 respondent farmers is 35 hectares. The research data shows that 19 farmers have a land area of 0.5 to 1 hectare with 63.33 percent. Then farmers with a land area of 1 to 2 hectares as many as 11 people with a 36.67 percent. These results indicate that cassava farmers in Ciseeng sub-district are classified as mediumscale farmers. The larger the land area, the higher the production that can be produced, and the income will increase. In other words, land area affects the amount of income received by farmers (Soekartawi, 2016).

\section{Experience in Farming}

Farming experience is one indicator that indirectly affects the success of cassava farming by farmers. Experienced farmers supported by complete production facilities will be more capable of increasing production than farmers who have just started farming. The data shows that the experience of cassava farming owned by the respondent farmers can be categorized as relatively high because most of them have 15 to 30 years of farming experience with 46.67 percent.

\section{Number of Dependents of the Family}

The number of dependents of the family is the total number of people in one household who are dependents of the head of the household. The number of dependents of farmer families ranges from 3 to 6 people with 70 percent. The average number of dependents of each farmer's family is 3 people, which means that respondent farmers must bear the number of family members is quite a lot.

Obinne cited in Amanze et al. (2010), argues that large household size in some cases can be advantageous because it is easy to find labor with affordable wages. Awoniyi et al. (2009) also argue that a large household size can help provide labor in the family for cassava farmers, thus leading to efficient use of resources.

\section{The Use of Cassava Farming Production Infrastructure}

Agricultural production will not get optimal results if good production facilities do not support it. Therefore, the production infrastructure in farming is essential.

\section{Land}

The land used for cassava farming in Ciseeng sub-district is entirely rainfed. Generally, cassava farmers in Ciseeng sub-district use the entire land to grow cassava specifically. The land used by all respondent farmers is their land. In the calculation of income analysis, land costs are land taxes, including cash costs. The average cost of land tax in Ciseeng sub-district is IDR 5,429,285.71 per hectare every year. According to Thamrin et al. (2013), the land area greatly determines the income of cassava 
farmers. If the land area is increased, the population of cassava will increase to increase cassava production.

\section{Seedlings}

All cassava farmers in Ciseeng sub-district obtain seeds from the stems of the previous plant, so the cost of seeds is taken into account. Seedlings are obtained from the rest of the cassava plant that has been harvested. The harvesting time of cassava varies according to the variety. For early maturing varieties, the harvest time reaches 6 to 8 months, and for varieties, in the harvest time, it comes 9 to 12 months (Ministry of Agriculture, 2019).

The varieties of cassava cultivated by farmers in Ciseeng sub-district are white cassava and yellow cassava (butter). The average use of cassava seeds in Ciseeng subdistrict is 7,897.14 stems per hectare. The number of seeds used is one factor that affects the level of income obtained. The more seeds used, the greater the opportunity to produce more products so that the income earned by farmers will increase (Udoh and Falake, 2006).

\section{Fertilizers and Pesticides}

Cassava is a plant that is easy to cultivate and can be planted even on less fertile land. However, special maintenance needs to be done so that production results are greater or optimal. Cassava farmers in Ciseeng sub-district carry out treatment by fertilizing and spraying pesticides.

Fertilization using chemical fertilizers and manure. Meanwhile, spraying pesticides using herbicides. The chemical fertilizers used are urea fertilizer, SP-36 fertilizer, ZA fertilizer, and NPK fertilizer. Based on the interviews, cassava farmers in Ciseeng sub-district face problems in the form of difficulty in obtaining subsidized fertilizers. The Farmer's Card is required to purchase subsidized fertilizers. However, many farmers in the Ciseeng sub-district do not yet have a Farmer Card.

The use of fertilizers and pesticides in Ciseeng sub-district varies according to the area of land owned. The average use of urea fertilizer is $162.93 \mathrm{~kg}$ per hectare, SP-36 fertilizer is $74.99 \mathrm{~kg}$ per hectare, ZA fertilizer is $35 \mathrm{~kg}$ per hectare, and NPK fertilizer is $73.81 \mathrm{~kg}$ per hectare. While the average use of manure is $987.14 \mathrm{~kg}$ per hectare. Then the moderate use of pesticides is $1974.29 \mathrm{ml}$ per hectare.

\section{Manpower}

The workers used in cassava farming in Ciseeng sub-district are Workers Outside the Family (TKLK) and Workers Within the Family (TKDK). Based on the interviews, TKLK and TKDK only consisted of men employed for land management, planting, fertilizing, spraying, and harvesting.

The wage system in cassava farming in Ciseeng sub-district is divided into piecerate wages and daily wages. Piece rate wages are wages given by the working time agreement with workers regardless of the length of time worked, while daily wages or time wages are wages provided based on the size of time worked (Suratiyah, 2015).

The piece-rate system is applied during land cultivation and planting, while the daily wage system is used during fertilizing, spraying, and harvesting. The average wage for TKLK is IDR 5,065,714.29 per hectare, and the average salary for TKDK is IDR $1,254,285.71$ per hectare. The use of labor must be carefully and taken into account because it can increase production costs (Kuye and Olufemi, 2015).

86| Rosilawati, N., K. Sukiyono, Sriyoto. Income Efficiency of Cassava Farming.... 


\section{Agricultural Equipment Tools}

Equipment tools used by cassava farmers in Ciseeng sub-district are hoe, kored, fork, sprayer, crowbar, and machete or machete. Each device has its function. Hoes are used in making mounds and hoes. Kored is used in weeding and a sprayer for spraying. Forks and crowbars have the same function: to cultivate the land so that it is loose.

Meanwhile, a machete is used to cut seeds and tubers. The cost of depreciation of agricultural equipment used during farming is calculated. The average depreciation value is IDR $108,635.71$ per hectare.

\section{Cassava Farming Revenue}

The amount of production per hectare and the selling price of tubers will affect farmer acceptance. The higher the production and selling price, the higher the farmer's income. The average price of tubers sold at the farmer level is IDR 1,017.14 per kilogram. Farmers lack bargaining power because the selling price is based on the price set by the middleman. The average amount of cassava production in Ciseeng subdistrict is $23,691.43 \mathrm{~kg}$ per hectare with average revenue of IDR $28,957,714.29$ per hectare.

\section{Cassava Farming Expenditure}

Cash expenditures on cassava farming in Ciseeng sub-district include the costs of inorganic fertilizers, organic fertilizers, pesticides, TKLK, and taxes. The largest percentage of expenditure is on land tax costs of 46.03 percent. The second largest percentage of expenditure is TKLK costs of 42.95 percent. The results of this study are not in line with research conducted by Muizah et al. (2013), which shows that the largest cost value is the cost of labor outside the family (TKLK) of IDR 3,526,900 per hectare or 45.07 percent of the total cost.

Table 1. Average Expenditure of Respondent Farmers' Cassava Farming per hectare in Ciseeng sub-district in 2020

\begin{tabular}{|c|c|c|c|c|c|c|}
\hline No & Components & Unit & Volume & Price & Total & Percentage \\
\hline \multirow[t]{7}{*}{1} & Variable Cost & IDR/ha & & & & \\
\hline & $\begin{array}{l}\text { Anorganic } \\
\text { Fertilizer }\end{array}$ & IDR/ha & 346,73 & 1.875 & $662.015,71$ & 5,61 \\
\hline & $\begin{array}{l}\text { Organic } \\
\text { Fertilizer }\end{array}$ & IDR/ha & 987,14 & 500 & $493.571,43$ & 5,61 \\
\hline & Pesticide & IDR/ha & 974,29 & 73,5 & $145.110,00$ & 1,23 \\
\hline & TKLK & IDR/ha & & & $5.065 .714,29$ & 42,95 \\
\hline & Tax & IDR/ha & & & 5.429 .286 & 46,03 \\
\hline & Total & IDR/ha & & & $11.795 .697,14$ & 100 \\
\hline \multirow[t]{5}{*}{2} & Fixed Cost & IDR/ha & & & & \\
\hline & Seeds/stems & IDR/ha & $7.897,14$ & 1.000 & $7.897 .142,86$ & 85,28 \\
\hline & $\begin{array}{l}\text { Depreciation } \\
\text { Cost }\end{array}$ & IDR/ha & & & $108.635,71$ & 1,17 \\
\hline & TKDK & IDR/ha & & & $1.254 .285,71$ & 13,55 \\
\hline & Total & IDR/ha & & & $9.260 .064,28$ & 100 \\
\hline 3 & Total Cost & IDR/ha & & & $21.055 .761,42$ & \\
\hline
\end{tabular}

Source: Processed Primary Data 2020 
(Rosyanni, Rizki. 2011) The third-largest expenditure percentage is the cost of inorganic fertilizers and organic fertilizers, which is 5.61 percent. In total, the fertilizer cost is 11.22 percent. The smallest percentage of cash expenditures is on pesticide costs of 1.23 percent. The total cash outlay on cassava farming in Ciseeng sub-district is IDR $11,795,697.14$ per hectare.

(Fadhlina Sosiawati, 2015) Expenditures calculated on cassava farming in Ciseeng sub-district include the cost of seeds, equipment depreciation, and TKDK. The largest percentage of expenditure is on the cost of seeds of 85.28 percent. The secondlargest percentage of expenditure is TKDK costs of 13.55 percent. The smallest percentage of expenses calculated is on equipment depreciation costs of 1.17 percent. The total cost of cassava farming in Ciseeng sub-district is IDR 9,260,064.28 per hectare.

The total expenditure on cassava farming in Ciseeng sub-district was IDR $21,055,761.42$ per hectare. These results are obtained from the sum of IDR $11,795,697.14$ per hectare cash costs with calculated expenses of IDR 9,260,064.28 per hectare. When compared, the cash outlay is greater than the calculated expense.

The results of this study are not in line with research conducted by Addinirwan (2014), which shows that cash expenditures are smaller than the calculated expenditures. Cash expenditures amounted to IDR 4,791,815.20 per hectare while the calculated expenditure was IDR 9,856,628.92 per hectare. Farmers use purchased seeds, so the cash costs are greater than the calculated costs.

\section{Efficiency of Cassava Farming Income}

Farmer income is the difference between cassava sales (production) and the total production costs incurred by cassava farmers (Muizah et al., 2013). Revenue consists of two components: income from cash costs and income from total costs. Income on cash costs is the difference between receipts and cash costs incurred by farmers, and income on total costs is the difference between receipts and total costs incurred by farmers. The income and income of a farm are very dependent on how the role of farmers in managing their farming.

Table 2. Cassava Farming Income in Ciseeng sub-district.

\begin{tabular}{ll}
\hline Components & Value (IDR/ha) \\
\hline A. Total Revenue & $28.957 .714,29$ \\
\hline B. Variable Cost & $11.795 .697,14$ \\
\hline C. Fixed Cost & $9.260 .064,29$ \\
\hline D. Total Cost (B+C) & $21.055 .761,43$ \\
\hline Gross Income (A-B) & $17.162 .017,14$ \\
\hline Net Income (A-D) & $7.901 .952,86$ \\
\hline R/C (Cash Cost) & 2,45 \\
\hline R/C (Total Cost) & 1,38 \\
\hline
\end{tabular}

Source: Processed Primary Data 2020

Farming is said to be efficient or not indicated by the value of the $\mathrm{R} / \mathrm{C}$ ratio. The value of the $R / C$ ratio is a comparison between the output and the input value, from which it can be seen whether a farm is efficient or not (Soekartawi, 2016). In more detail, the income of cassava farming in Ciseeng sub-district can be seen in Table 2. The analysis results show that the income from cash costs and total costs in cassava

90| Rosilawati, N., K. Sukiyono, Sriyoto. Income Efficiency of Cassava Farming.... 
farming in Ciseeng sub-district has a value greater than zero. Income from cash costs is IDR $17,162,017.14$ per hectare, and income from total costs is IDR 7,901,952.86 per hectare, which means that farming activities can be profitable or feasible to cultivate. The value of the $\mathrm{R} / \mathrm{C}$ ratio of cash and total costs has more than one value. The value of the $\mathrm{R} / \mathrm{C}$ ratio for cash costs is 2.45 and for total costs is 1.38 . This shows that every rupiah of cash costs incurred for cassava farming will generate a revenue of IDR 2.45. Each rupiah of total costs incurred for cassava farming will generate IDR 1.38 . Therefore, based on the value of the $\mathrm{R} / \mathrm{C}$ ratio, it can be shown that cassava farming in Ciseeng sub-district can continue to be carried out by farmers to increase their income.

Based on the analysis results, it can be concluded that cassava farming activities in Ciseeng sub-district, Bogor Regency, are efficient or feasible to cultivate. The results of this study are in line with research conducted by Nur Amri (2011), which shows that income on cash costs is IDR $10,799,012.60$ and income for total costs is IDR $6,279,598.36$. The value of the $R / C$ ratio for cash costs is 2.80 and for total costs is 1.59 .

\section{CONCLUSIONS AND POLICY IMPLICATIONS}

\section{Conclusions}

1. Cassava farming in Ciseeng sub-district is carried out by farmers of productive age, namely on an age scale of 45-54 years. The level of formal education of farmers in Ciseeng sub-district is still relatively low because elementary school graduates dominate it. The land area of cassava farmers in Ciseeng sub-district is quite large, with an average land area of 1.47 hectares. Most of the farmers have 15 to 30 years of farming experience. The number of dependents of farmer families ranges from 3 to 6 people, with the average number of dependents of each farmer's family being three people.

2. 2. The cash income is IDR $27,303,209.09$ per hectare, and the total cost is IDR $12,650,592.93$ per hectare. While the $\mathrm{R} / \mathrm{C}$ ratio of cash costs is 2.45 and total costs are 1.38. So, it can be said that cassava farming in Ciseeng sub-district is efficient or feasible to cultivate.

\section{Recommendation}

Suggestions for cassava farming as a commodity that can be continuously cultivated in order to increase farmers' income in Ciseeng sub-district. There needs to support from the local government of Bogor Regency to develop cassava farming. Future research is expected to analyze the performance of agriculture to describe the actual condition of cassava farming in Ciseeng sub-district.

\section{REFERENCES}

Adeyemo, R., Oke J.T.O., dan Akinola A.A. 2010. Economic Efficiency of Small Scale Farmers in Ogun State, Nigeria. Tropicultural Journal, Vol. 28 (2): $84-88$.

Addinirwan, Luqman. 2014. Analisis Pendapatan dan Efisiensi Teknis Usahatani Ubi Kayu di Desa Galuga Kecamatan Cibungbulang Kabupaten Bogor. Skripsi. Fakultas Ekonomi dan Manajemen. Institut Pertanian Bogor.

Amanze, B., Eze C.C., dan Eze V. 2010. Factors Influencing the Use of Fertilizer in Arable Crop Production among Smallholder Farmers in Owerri Agricultural Zone of Imo State, Nigeria. Academia Arena Journal, Vol. 2 (6): 90 - 96. 
Awoniyi, O.A., Awoyinka Y.A., dan Kehinde, A.L. 2009. Effect of the Presidential Initiative on Cassava and Household Food Security Status in Iwo Zone of Osun State Agricultural Development Programme. African Crop Science Conference Proceedings. Hal: $755-760$.

Arikunto. 2010. Prosedur Penelitian Suatu Pendekatan Praktik. Rineka Cipta. Jakarta.

Bamidele, F.S., Babatunde R.O., dan Rasheed A. 2008. Productivity Analysis of Cassava-based Production Systems in the Guinea Savannah: Case study of Kwara State, Nigeria. American-Eurasian Journal of Scientific Research, Vol. 3 (1): $33-39$.

Dinas Tanaman Pangan, Hortikultura, dan Perkebunan. 2018. Luas Lahan, Produktivitas, dan Produksi Ubi Kayu di Kabupaten Bogor. Distanhorbun Kabupaten Bogor. Bogor. https://distanhorbun.bogorkab.go.id [16 Oktober 2019].

Fadhlina Sosiawati, 2015. Analisis Efisiensi Tknis, Pendapatan dan Pemasaran Ubi Kayu di Kabupaten Lampung Tengah. Skripsi. Fakultas Ekonomi dan Manajemen. Institut Pertanian Bogor.

Kementerian Pertanian. 2016. Outlook Komoditas Pertanian Sub Sektor Tanaman Pangan: Ubi Kayu. Kementerian Pertanian Republik Indonesia. Jakarta.

Kuye dan Olufemi Oludayo. 2015. Comparative Analysis of Constraints to Cassava Production by Cassava Farmer Loan Beneficiaries and Loan Non-Beneficiaries in South-South Nigeria. Global Journal of Agricultural Research, Vol. 3 (3): 38 52.

Muizah, Rofiatul., Suprapti Supardi., dan Shofia Nur Awami. 2013. Analisis Pendapatan Usahatani Ubi Kayu (Manihot esculenta crantz) (Studi Kasus Desa Mojo Kecamatan Cluwak Kabupaten Pati). Jurnal MEDIAGRO, Vol. 9 (2): 55 - 67.

Nandi, J. A., Gunn P., dan Yurkushi E.N. 2011. Economic Analysis of Cassava Production in Obubra Local Government Area of Cross River State, Nigeria. Asian Journal of Agricultural Science, Vol. 3 (3): 205 - 209.

Nur Amri, Alfian. 2011. Analisis Efisiensi Produksi dan Pendapatan Usahatani Ubi Kayu (Studi Kasus Desa Pasirlaja, Kecamatan Sukaraja, Kabupaten Bogor). Skripsi. Fakultas Ekonomi dan Manajemen. Institut Pertanian Bogor.

Rahmadona, Lola., Anna Fariyanti., dan Burhanuddin. 2015. Analisis Pendapatan Usahatani Bawang Merah di Kabupaten Majalengka. Jurnal AGRISE, Vol. 15 (2): $73-84$.

Rosyanni, Rizki. 2011. Analisis Pendapatan Usahatani, Pemasaran dan Nilai Tambah Ubi Kayu Skripsi. Departemen Agribisnis, Fakultas Ekonomi dan Manajemen, Institut Pertanian Bogor

Sayogyo. 1977. Golongan Miskin dan Partisipasi dalam Pembangunan (Poor Household dan Thei Participation in Development). Prisma, Vol. 6 (3): 10 - 17.

Soekartawi. 2016. Analisis Usahatani. UI Press. Jakarta

Suratiyah, Ken. 2015. Ilmu Usahatani. Penebar Swadaya. Jakarta.

Tjiptoherijanto, Prijono. 2001. Proyeksi Penduduk, Angkatan Kerja, Tenaga Kerja, dan Peran Serikat Pekerja dalam Peningkatan Kesejahteraan. BAPPENAS. https://www.bappenas.go.id [16 Oktober 2019].

Udoh, E. J., dan Falake O. 2006. Resource-use Efficiency and Productivity among Farmers in Nigeria. Journal of Agriculture and Social Sciences, Vol. 2 (4): $264-$ 269

90| Rosilawati, N., K. Sukiyono, Sriyoto. Income Efficiency of Cassava Farming.... 